\title{
Heavy Metal Speciation Study of Water and Bottom Sediments from River Wujam in Chip District of Pankshin Local Government Area, Plateau State, Nigeria
}

\author{
I.L. Dapam ${ }^{1, *}$, E.G. Ibrahim², J.D. Dodo ${ }^{3}$ \\ ${ }^{1}$ Foundations Academy, Sub - Mashiah Foundation, Plateau State, Nigeria \\ ${ }^{2}$ Department of Chemistry, Plateau State University, Nigeria. \\ ${ }^{3}$ Department of Chemistry, University Jos, Jos, Nigeria.
}

\section{ARTICLE DETAILS}

\section{Article history:}

Received 14 February 2018

Accepted 06 March 2018

Available online 09 March 2018

\section{Keywords:}

Heavy Metals

Speciation Studies

Bioavailability

Seasonal Assessment

\begin{abstract}
A B S T R A C T
Heavy metal species of water and bottom sediment samples from River Wujam in Chip district of Pankshin L.G.A. were investigated in the dry and wet seasons. The analysis was done using standard procedures. The results for the total metal concentration of the water samples ranges, thus, $0.02-0.03$ $\mathrm{mg} / \mathrm{L}$ for copper, $0.01-0.11 \mathrm{mg} / \mathrm{L}$ for lead, $0.02-0.07 \mathrm{mg} / \mathrm{L}$ for manganese, $0.01-0.06 \mathrm{mg} / \mathrm{L}$ for cadmium. But nickel and zinc were not detected within the limits used. The total metal concentration of metals analysed $(\mathrm{Cu}, \mathrm{Pb}, \mathrm{Mn}, \mathrm{Cd}, \mathrm{Zn}$, and $\mathrm{Ni})$ in the sediments revealed a generally higher concentration in the dry season except for cadmium which revealed a higher concentration in the wet season. Speciation of the metals was also carried out on the sediments using Tessier method to determine their distribution in the sediment of the river. The percentage ranges of the fractions for the dry season are, $12.24-46.09 \%, 15.80-24.01 \%, 11.47-21.91 \%, 10.83-22.80 \%$, and $7.61-75.00 \%$ for exchangeable, carbonate, Fe-Mn oxide, organic, and residual fractions respectively. Ni was not detected within the limits used in the carbonate, Fe-Mn oxide and organic fractions. The range of fractions for the wet season are, $4.25-33.77 \%, 10.82-24.21 \%, 15.91-38.35 \%, 10.65-51.06 \%$, and $19.01-26.77 \%$ for exchangeable, carbonate, Fe-Mn oxide, organic, and residual fractions respectively. Ni was not detected within the limits used in the carbonate and organic fractions. With change in the environmental conditions Cadmium and lead bound to such labile phases in both the dry and wet season, can easily remobilize in the water system. A moderate positive correlation existed in the total metal concentration of water samples between dry and wet seasons. A strong positive correlation existed in the total metal concentration in the sediments samples between dry and wet seasons. T-test results indicated that there is no significant variation in the concentrations between the seasons in both cases.
\end{abstract}

\section{Introduction}

Heavy metals among other indicators of water and sediment pollution has remained a major source of concern to researchers [1-5]. This is because they could cause a negative effect to human health and the aquatic system. Heavy metals are persistent in nature, toxic, and have a very high tendency to accumulate in living organisms and get adsorbed on sediment particles [6, 7]. A good number of researchers [ 2,4, 8-10] have reported that sediments/soils are not only basic components of our environment as they provide nutrients for living organisms, but also serve as an important sinks for pollutants that are deleterious to health, particularly heavy metals. They also play a significant role in re-mobilization of contaminants in aquatic systems when certain conditions prevail eg., $\mathrm{pH}$, redox potential, desorption or (bio) degradation of the sorptive substances [11]. Therefore it is very appropriate to study it, to know its level of contamination with metals and to determine its interaction with the water body. The determination of only total element concentration in sediments does not give an accurate estimate of the likely environmental impacts regarding their bioavailability, mobility, toxicity and reactivity $[1,11,9]$. Hence, speciation analysis (sequential extraction), the partitioning of metal contaminants between specific forms, to investigate their geochemical composition and distribution in the sediments is used [12-14] whereby, components loosely held in the soil are extracted first, followed by those that are more tightly bonded, the sequential solubilisation of the various substrates that make up the sediments $[11,15]$. It has the following advantages over the determination of total metal concentration as it tells the source of metal, weather natural (lithogenic) or anthropogenic [10], its toxicity to living organism (biota) and a higher knowledge of metal- sediment interaction [16]. The sequential extraction was based on the fivestage sequential extraction procedure [17] which has been used to divide heavy metals into different binding forms: exchangeable, carbonatebound, Fe-Mn Oxide-bound, Organic matter/Sulfide bound and Residual [1]. The aim of the present research is to study the status of heavy metal speciation of river Wujam. The results obtained from this study will provide information on the level of concentration of heavy metals in water and sediment, thereby contributing to the effective monitoring of environmental quality and health of the ecosystem.

\section{Experimental Methods}

\subsection{Study Area}

Mhiship community or Chip community is comprised of people whose tribe is called Mhiship or Chip. It is located around the hills in southern part of Pankshin local government area of Plateau state. It is located between kilometers 50 and 58 along Panyam - Shendam road. They are surrounded by hills and mountains in the north, which has the local government council secretariat/headquarters and plain land that leads to Shendam and Quan-Pan local government areas in the south [11]. The main occupation of the inhabitants of the area is farming and tapping of palm wine. The major sources of water in Chip are the rivers with a very few boreholes. The source of water identified for this project work is River Wujam. The source of water is under consistent attack by human and animal activities such as washing, bathing, excreting, urinating, agricultural activities and cattle rearing. 


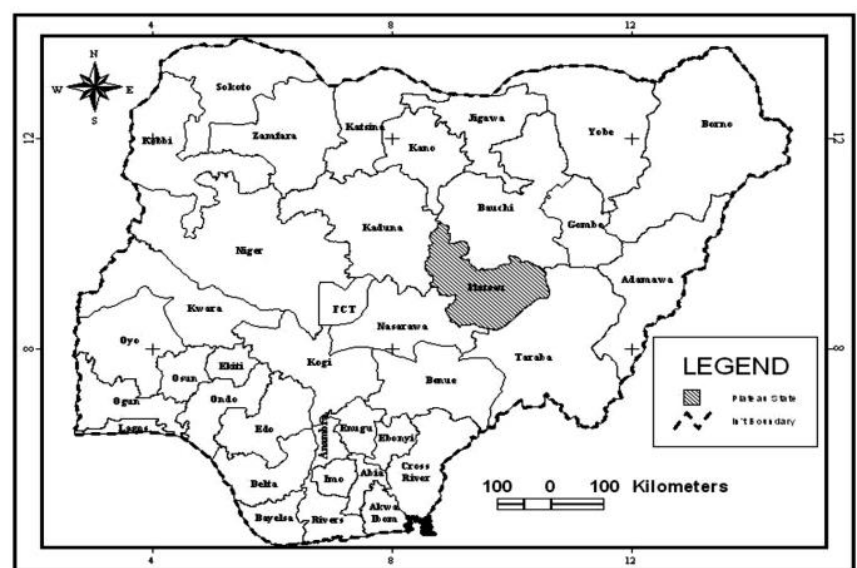

Fig. 1 Map of Nigeria showing Plateau State

\section{PLATEAU STATE MAP}

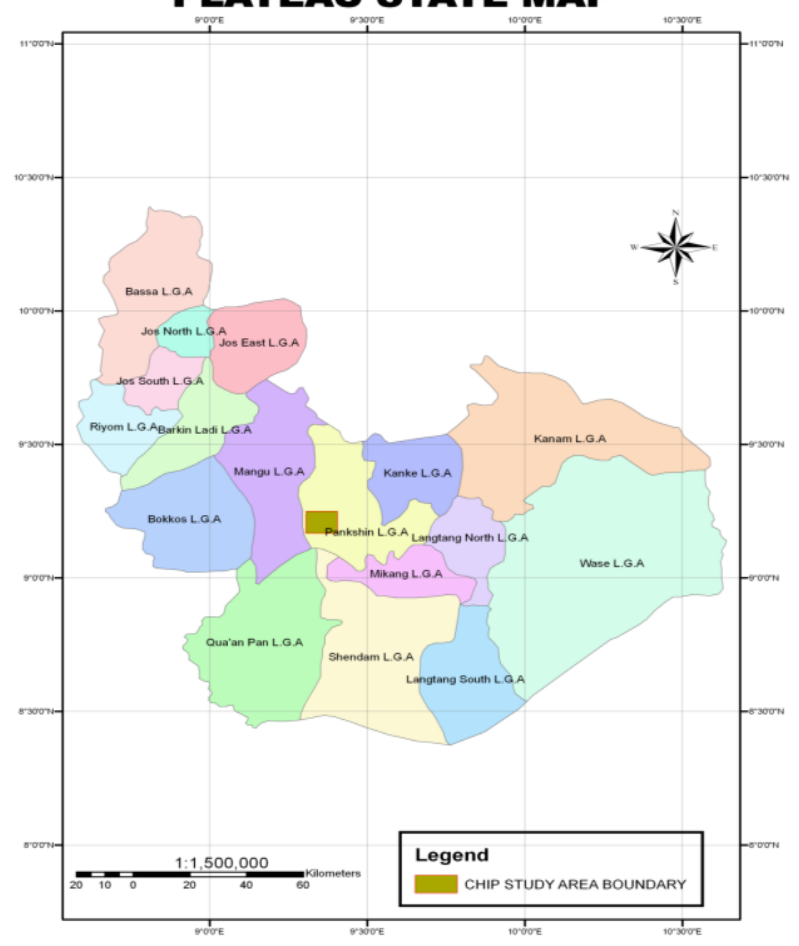

Fig. 2 Map of Plateau State showing Pankshin L.G.A.

\subsection{Sample Collection}

\subsubsection{Water Sample Collection}

The sample containers ( 2 L plastic containers with a screw cap) were washed with detergent, leached with concentrated $\mathrm{HNO}_{3}$, rinsed with distilled water until acid free and finally with the water sources. And were labelled appropriately. Grap samples of water were collected from four different locations singly (at about 500 meters interval) along the rivers into the prepared containers manually. This was done in January, Febuary and March for the dry season and June, July and August for the wet season of the year. The samples were collected, a few drops of Hydrogen Trioxonitrate $(\mathrm{v})$ acid was added at the point of collection and then preserved at $4{ }^{\circ} \mathrm{C}$ prior further analysis $[5,18]$.

\subsubsection{Sediment Sample Collection and Treatment}

Sediments samples were collected alongside the water samples using a stainless steel scoop into a polyethylene bags previously soaked with dilute nitric acid for $24 \mathrm{hrs}$, rinsed with distilled water and dried. The grab samples of surface sediments were taken at a depth of $0-5 \mathrm{~cm}$ for the various months for the dry and wet seasons [19]. These samples were then transported to Postgraduate Chemistry Laboratory University of Jos, Nigeria, and air dried for about two weeks at room temperature and grinded with mortar and pestle. The ground soil samples were sieved using $0.2 \mathrm{~mm}$ sieve size and kept in a poly ethylene bottle for further analysis.

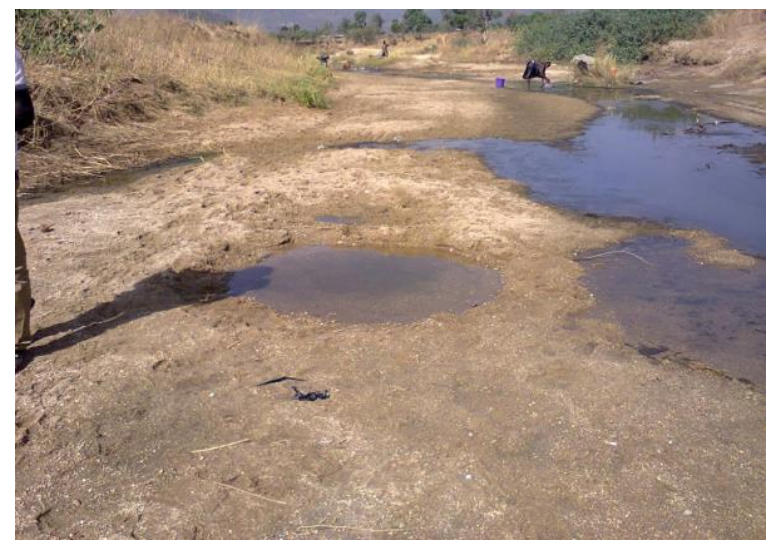

Fig. 3 River Wujam in the dry season

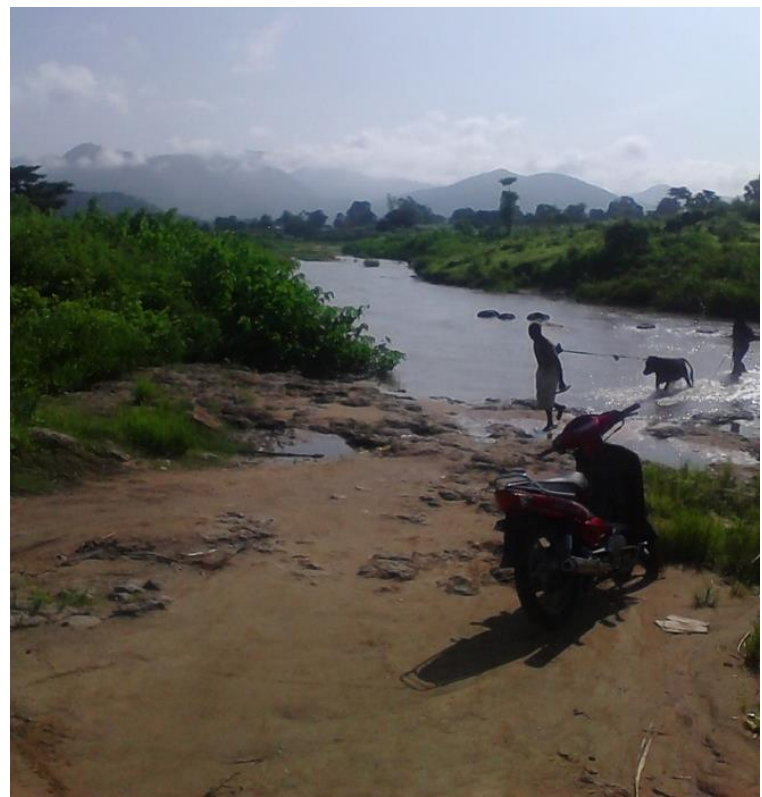

Fig. 4 River Wujam in the wet season

\subsection{Methodology}

Water samples were analysed for metallic elements using atomic absorption spectrophotometric method after digestion [5]. The digestion of the sediment sample for the determination of total metal was done using aqua regia. The sequential method was used to determine the speciation of the metals studied in the sediments [17]. These five sequential procedure was used [20] which were,

1. A $1.00 \mathrm{~g}$ triplicate dried sieved soil sample from each sampling site was shaken with $20 \mathrm{~cm}^{3}$ of $1 \mathrm{M} \mathrm{MgCl}_{2}$ at $\mathrm{pH} 7$ for 1 hour, filtered and analysed for exchangeable fraction.

2. The residue of the exchangeable fraction was shaken with $20 \mathrm{~cm}^{3}$ $\mathrm{CH}_{3} \mathrm{COONa}$ at room temperature for $5 \mathrm{~h}$ at $\mathrm{pH} 5$, then filtered and analysed for the carbonate fraction.

3. The residue of the carbonate fraction was digested with a mixture of $10 \mathrm{~cm}^{3} 0.04 \mathrm{M} \mathrm{NH}_{2} \mathrm{OH} . \mathrm{HCl}$ and $10 \mathrm{~cm}^{3}$ of $25 \% \mathrm{CH}_{3} \mathrm{COOH}$ at $96{ }^{\circ} \mathrm{C}$ for 6 $\mathrm{h}$, then filtered and analysed for the Fe-Mn oxide/reducible fraction.

4. The residue of the Fe-Mn oxide/reducible fraction was transferred into $250 \mathrm{~cm}^{3}$ beaker and $9 \mathrm{~cm}^{3}$ of $0.02 \mathrm{M} \mathrm{HNO}_{3}$ and $15 \mathrm{~cm}^{3}$ of $30 \% \mathrm{H}_{2} \mathrm{O}_{2}$ were added, the mixture was heated for $5 \mathrm{~h}$ at $85^{\circ} \mathrm{C}$ on a water bath After $2 \mathrm{~h}$ of heating, another $15 \mathrm{~cm}^{3}$ of $30 \% \mathrm{H}_{2} \mathrm{O}_{2}$ was added. This was then filtered and analysed for the organic fraction.

5. The residue of the organic fraction was digested with aqua regia (7.5 $\mathrm{cm}^{3}$ of $37 \% \mathrm{HCl}$ and $2.5 \mathrm{~cm}^{3}$ of $\mathrm{HNO}_{3}$ ) at $85^{\circ} \mathrm{C}$ for $1 \mathrm{~h}$ and then filtered and analysed for the residual fraction.

\subsection{Statistical Analysis}

The results obtained for heavy metals in the water and sediments in Tables 1 and 2 were subjected to statistical analysis such as correlation coefficient and t-test. The Spearman's rank correlation coefficient was employed to determine the correlation. 


\section{Results and Discussion}

Table 1 shows the results for the heavy metal analysis. The mean concentration reveals a lower values for copper and manganese in the wet and dry season based on the WHO standard. Lead was $0.01 \mathrm{mg} / \mathrm{L}$ in the dry and $0.11 \mathrm{mg} / \mathrm{L}$ in the wet seasons which is slightly higher than the WHO standard. Cadmium also shows a slightly higher values of $0.01 \mathrm{mg} / \mathrm{L}$ and $0.06 \mathrm{mg} / \mathrm{L}$ in the dry and wet seasons respectively. However the concentrations of zinc and nickel were below the detection limits of the instruments used. The correlation of 0.4286 indicates that there exist a moderate positive correlation in metal concentration of water samples between dry and wet seasons in River Wujam. The critical value of $t$ at $5 \%$ significant level with 10 degrees of freedom is \pm 2.228 . Hence, comparing the calculated value $(-0.7086)$ and the critical value, the null hypothesis cannot be rejected. Thus, it can be concluded that there exist no significant variation in the total metal concentration of water samples between dry and wet seasons of River Wujam.

Table 1 The total metal concentration (mg/L) of the water samples of River Wujam

\begin{tabular}{lllll}
\hline Parameters(Mg/L) & Dry season & Wet season & WHO & SON \\
\hline Copper & $0.02 \pm 0.01$ & $0.03 \pm 0.01$ & 1.3 & 1.3 \\
Lead & $0.01 \pm 0.002$ & $0.11 \pm 0.01$ & 0.01 & 0.01 \\
Manganese & $0.07 \pm 0.03$ & $0.02 \pm 0.001$ & 0.1 & 0.05 \\
Zinc & BDL & BDL & 0.1 & 5.0 \\
Cadmium & $0.01 \pm 0.01$ & $0.06 \pm 0.03$ & 0.01 & 0.003 \\
Nickel & BDL & BDL & 0.07 & 0.02 \\
\hline
\end{tabular}

$B D L=$ Below detection limits

Table 2 Total metal concentration (mg/Kg) of the sediments of River Wujam

\begin{tabular}{lllllll}
\hline Sesson & $\mathrm{Cu}$ & $\mathrm{Pb}$ & $\mathrm{Mn}$ & $\mathrm{Zn}$ & $\mathrm{Cd}$ & $\mathrm{Ni}$ \\
\hline Dry & $0.11 \pm 0.02$ & $0.23 \pm 0.02$ & $1.56 \pm 0.21$ & $3.36 \pm 0.31$ & $0.07 \pm 0.01$ & $0.12 \pm 0.02$ \\
Wet & $0.10 \pm 0.01$ & $0.19 \pm 0.01$ & $0.35 \pm 0.01$ & $3.09 \pm 0.32$ & $0.09 \pm 0.02$ & $0.06 \pm 0.02$
\end{tabular}

Table 3 Concentration ( $\mathrm{mg} / \mathrm{Kg}$ ) of sequential fraction of metals in sediments of River Wujam at the Dry season ( $\mathrm{RW}_{\mathrm{D}}$ )

\begin{tabular}{lllllll}
\hline Fraction & $\mathrm{Cu}$ & $\mathrm{Pb}$ & $\mathrm{Mn}$ & $\mathrm{Zn}$ & $\mathrm{Cd}$ & $\mathrm{Ni}$ \\
\hline Exchangeable & $0.03 \pm 0.01$ & $0.21 \pm 0.01$ & $0.35 \pm 0.02$ & $4.06 \pm 0.12$ & $0.06 \pm 0.02$ & $0.02 \pm 0.01$ \\
Carbonate & $0.05 \pm 0.02$ & $0.21 \pm 0.01$ & $0.18 \pm 0.04$ & $3.93 \pm 0.10$ & $0.04 \pm 0.01$ & $\mathrm{BDL}$ \\
Fe- Mn Oxide & $0.04 \pm 0.01$ & $0.19 \pm 0.02$ & $0.09 \pm 0.03$ & $4.49 \pm 0.49$ & $0.05 \pm 0.01$ & $\mathrm{BDL}$ \\
Organic fraction & $0.05 \pm 0.01$ & $0.18 \pm 0.01$ & $0.08 \pm 0.02$ & $4.56 \pm 0.13$ & $0.05 \pm 0.02$ & $\mathrm{BDL}$ \\
Residual & $0.05 \pm 0.02$ & $0.23 \pm 0.01$ & $0.06 \pm 0.01$ & $4.77 \pm 0.10$ & $0.03 \pm 0.01$ & $0.06 \pm 0.02$ \\
\hline
\end{tabular}

Table 4 Percent (\%) of metal sequential fraction of metals in sediment of River Wujam at the dry season $\left(\mathrm{RW}_{\mathrm{D}}\right)$

\begin{tabular}{lllllll}
\hline Fraction & $\mathrm{Cu}$ & $\mathrm{Pb}$ & $\mathrm{Mn}$ & $\mathrm{Zn}$ & $\mathrm{Cd}$ & $\mathrm{Ni}$ \\
\hline Exchangeable & 12.24 & 20.43 & 46.09 & 18.63 & 25.44 & 25 \\
Carbonate & 22.35 & 20.56 & 24.01 & 18.02 & 15.80 & $\mathrm{BDL}$ \\
Fe - Mn Oxide & 19.13 & 18.50 & 11.47 & 20.59 & 21.91 & $\mathrm{BDL}$ \\
Organic fraction & 21.28 & 17.79 & 10.83 & 20.89 & 22.80 & $\mathrm{BDL}$ \\
Residual & 25.00 & 22.70 & 7.61 & 21.86 & 14.06 & 75 \\
\hline
\end{tabular}

Table 5 Concentration ( $\mathrm{mg} / \mathrm{Kg}$ ) of sequential fraction of metals in sediments of River Wujam at the wet season $\left(\mathrm{RW}_{\mathrm{W}}\right)$

\begin{tabular}{lllllll}
\hline Fraction & $\mathrm{Cu}$ & $\mathrm{Pb}$ & $\mathrm{Mn}$ & $\mathrm{Zn}$ & $\mathrm{Cd}$ & $\mathrm{Ni}$ \\
\hline Exchangeable & $0.04 \pm 0.02$ & $0.16 \pm 0.08$ & $0.06 \pm 0.02$ & $3.88 \pm 0.45$ & $0.10 \pm 0.03$ & $0.02 \pm 0.01$ \\
Carbonate & $0.06 \pm 0.03$ & $0.16 \pm 0.05$ & $0.28 \pm 0.06$ & $4.00 \pm 0.89$ & $0.03 \pm 0.01$ & $\mathrm{BDL}$ \\
Fe - Mn Oxide & $0.11 \pm 0.04$ & $0.17 \pm 0.06$ & $0.57 \pm 0.05$ & $4.26 \pm 0.91$ & $0.05 \pm 0.02$ & $0.01 \pm 0.001$ \\
Organic fraction & $0.03 \pm 0.01$ & $0.19 \pm 0.05$ & $0.29 \pm 0.08$ & $3.90 \pm 0.84$ & $0.04 \pm 0.01$ & $0.04 \pm 0.01$ \\
Residual & $0.06 \pm 0.02$ & $0.15 \pm 0.01$ & $0.29 \pm 0.07$ & $3.96 \pm 0.63$ & $0.08 \pm 0.03$ & $\mathrm{BDL}$ \\
\hline
\end{tabular}

Table 6 Percent (\%) of metal sequential fraction of metals in sediments of River Wujam at the wet season $\left(\mathrm{RW}_{\mathrm{W}}\right)$

\begin{tabular}{lllllll}
\hline Fraction & $\mathrm{Cu}$ & $\mathrm{Pb}$ & $\mathrm{Mn}$ & $\mathrm{Zn}$ & $\mathrm{Cd}$ & $\mathrm{Ni}$ \\
\hline Exchangeable & 13.68 & 24.66 & 4.25 & 19.42 & 33.77 & 32.63 \\
Carbonate & 20.14 & 24.21 & 18.82 & 20.00 & 10.82 & $\mathrm{BDL}$ \\
Fe - Mn Oxide & 36.52 & 26.91 & 38.35 & 21.28 & 15.91 & 16.31 \\
Organic fraction & 10.65 & 30.29 & 19.37 & 19.50 & 12.73 & 51.06 \\
Residual & 19.01 & 24.32 & 19.21 & 19.80 & 26.77 & $\mathrm{BDL}$ \\
\hline
\end{tabular}

The results for the total metal concentration of sediments in Table 2 revealed a higher concentration of copper $(0.11 \mathrm{mg} / \mathrm{kg})$, lead $(0.23$ $\mathrm{mg} / \mathrm{kg})$, manganese $(1.56 \mathrm{mg} / \mathrm{kg})$, zinc $(3.36 \mathrm{mg} / \mathrm{kg})$ and nickel $(0.12$ $\mathrm{mg} / \mathrm{kg}$ ) in the dry season as compared to the wet season. However Cadmium showed a higher concentration in the wet season with 0.09 $\mathrm{mg} / \mathrm{kg}$. The results for the metal analysis in the sediments of the river in both seasons were within the guidelines for sediments quality. The correlation coefficient of 0.8143 indicates that there exists a strong https://doi.org/10.30799/jespr.119.18040102 positive correlation in total metal concentration of the sediments between dry and wet seasons of River Wujam. The critical value of $t$ at $5 \%$ significant level with 10 degrees of freedom is 2.228 . Hence, comparing the calculated value $(0.2632)$ with the critical value, the null hypothesis cannot be rejected and it can be concluded that there exist no significant variation in the total metal concentration of the water samples between dry and wet seasons of River Wujam. Correlation and t-test analysis of total metal concentration of water and sediment was also carried out. For the dry season, the Correlation value of 0.2143 reveal a very weak positive correlation in total metal concentration between water and sediment. The critical value of $t$ at $5 \%$ significant level with 10 degrees of freedom is 2.228 . Hence, comparing the calculated value $(-1.6454)$ with the critical value, the null hypothesis cannot be rejected and it is concluded that there exist no significant variation in the total metal concentration of water and sediments. For the wet season, the Correlation value of -0.0571 reveal a weak negative correlation in total metal concentration between water and sediment. The critical value of $t$ at $5 \%$ significant level with 10 degrees of freedom is 2.228 . Hence, comparing the calculated value $(-1.2303)$ with the critical value, the null hypothesis cannot be rejected and it is concluded that there exist no significant variation in the water and sediments samples.
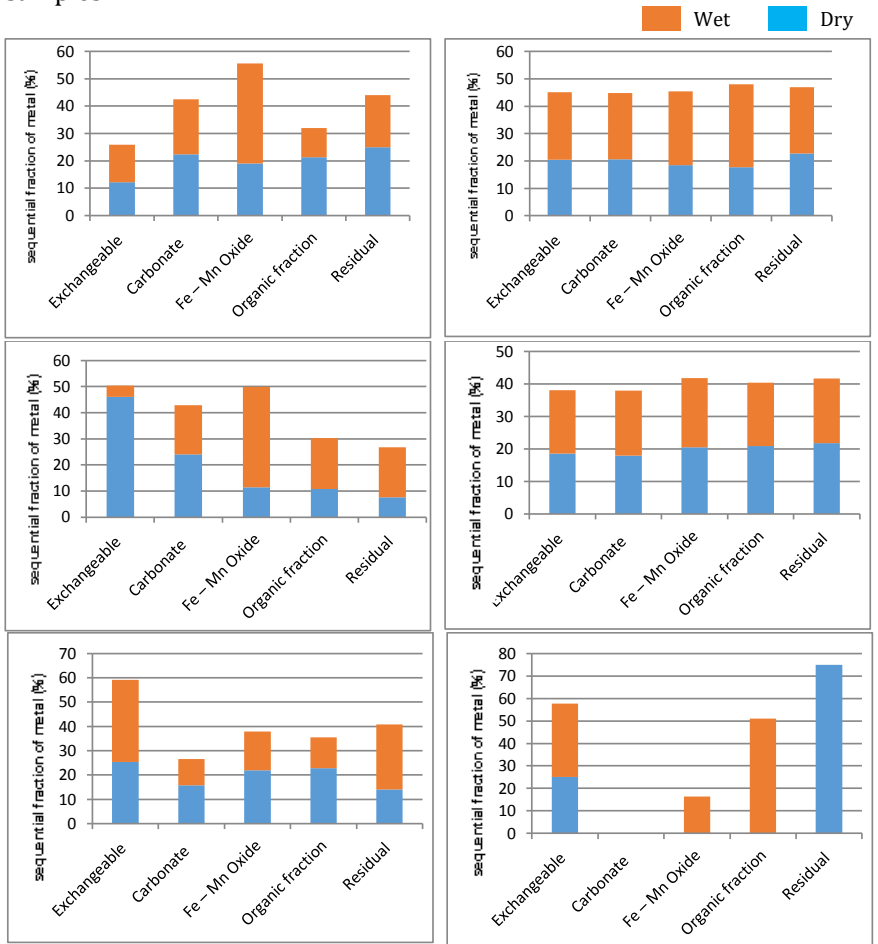

Fig. 5 The speciation pattern of $\mathrm{Cu}, \mathrm{Pb}, \mathrm{Mn}, \mathrm{Zn}, \mathrm{Cd}$ and Ni respectively in the dry and wet season of the study period presented as percentage fraction of metal species

Tables 3 and 5 show the concentration $(\mathrm{mg} / \mathrm{Kg}$ ) of sequential fraction of metals in the sediments. The results were converted to percent as shown in Tables 4 and 6 and were used to plot graphs for the patterns as shown in Fig. 5. The speciation pattern for copper in the sediments of River Wujam indicates the highest percentage of copper in the Fe-Mn oxide 0.11 $\pm 0.04 \mathrm{mg} / \mathrm{Kg})$ followed by the residual $(0.05 \pm 0.02 \mathrm{mg} / \mathrm{Kg})$ in the wet and dry seasons respectively. This indicates that copper is not bioavailable in the river being investigated but certain conditions can remobilize it in the wet season. The speciation pattern for lead in the sediments of River Wujam indicates that lead has the highest percentage in the residual fraction $(0.23 \pm 0.01 \mathrm{mg} / \mathrm{Kg})$ and organic fraction $(0.19 \pm 0.05 \mathrm{mg} / \mathrm{Kg})$ in the dry and wet season respectively. Although, the concentrations of the other fractions were considerably high. This indicates that lead may be bio-available to living organism in the study area. The speciation pattern for manganese in the sediments of River Wujam for the dry season indicates an occurrence of the highest concentration of manganese in the exchangeable fraction $(0.35 \pm 0.02 \mathrm{mg} / \mathrm{Kg})$ and decreasing with the least in the residual fraction $(0.06 \pm 0.01 \mathrm{mg} / \mathrm{Kg})$. In the wet season the highest percentage of manganese occurred in the Fe-Mn oxide fraction $0.57 \pm$ $0.05 \mathrm{mg} / \mathrm{Kg}$ ). The speciation pattern for zinc in the sediments of River Wujam indicates that zinc has the highest percentage in the dry and wet season in the residual fraction $(4.77 \pm 0.10 \mathrm{mg} / \mathrm{Kg})$ and Fe-Mn oxide fraction $(4.26 \pm 0.91 \mathrm{mg} / \mathrm{Kg})$ respectively. This indicates that zinc will not be released easily into the water layers when environmental conditions changes. This may suggest why zinc was below the detection limits in the water samples analysed from the river in both season. The speciation 
pattern for cadmium in the sediments of the river shows an occurrence of the highest percentage of cadmium in dry and wet seasons in the exchangeable fractions with $(0.06 \pm 0.02 \mathrm{mg} / \mathrm{Kg})$ and $(0.10 \pm 0.03 \mathrm{mg} / \mathrm{Kg}$ ) respectively. This study reveals that the percentage of cadmium in the exchangeable fractions in River Wujam in the dry and wet seasons are labile, highly toxic and the most bioavailable. The speciation pattern of nickel in the sediments of River Wujam reveal that nickel was only detected in the exchangeable $(0.02 \pm 0.01 \mathrm{mg} / \mathrm{Kg})$ and residual fractions $(0.06 \pm 0.02 \mathrm{mg} / \mathrm{Kg})$ in the dry season. In the wet season $\mathrm{Ni}$ was below the detection limits in the carbonate and residual fractions and the highest percentage of it was in the organic fraction $(0.04 \pm 0.01 \mathrm{~g} / \mathrm{Kg})$. This indicates that $\mathrm{Ni}$ is not bioavailable or cannot be mobilized. This may suggest the results obtained for $\mathrm{Ni}$ in the water samples from the same river, where it was below the detection limit.

\section{Conclusion}

There is quite a variation in the heavy metal content of river Wujam in the wet and dry season. The water samples obtained in the wet season have a higher concentration of the metals than the samples obtained in the dry season except manganese that reveals the contrary. Heavy metal content of the sediments samples in the dry season is higher than the sediments samples obtained in the wet season except for cadmium that reveals the contrary. The speciation analysis reveals that $\mathrm{Pb}, \mathrm{Mn}, \mathrm{Cd}$ exist generally more in fractions that can easily be mobilized and are bioavailable in the water system.

\section{References}

[1] B. Agnieska, T. Marek, Assessment of heavy metals mobility and toxicity in contaminated sediments by sequencial extraction and battery of bioassays, Ecotoxicol. 24 (2015) 1279-1293.

[2] M.M. Ali, M.L. Ali, S.Md. Islam, Z.Md. Rahman, Preliminary assessment of heavy metals in water and sediments of Karnaphuli River, Bangladesh, Environ. Nanotechnol. Monitor. Manag. 2 (2016) 27-35.

[3] T.C. Edet, E.E. Ubuo, Levels of heavy metals in the sediments from Itu River, Akwa Ibom, Nigeria, Int. Jour. Environ. Bioener. 5 (2013) 96-98.

[4] D.U. Essien, O.O. Nnanake-Abasi, E. Samuel, B.E. John, Distribution of trace metals in surface water and sediments of Imo River Estuary (Nigeria): Health risk assessment, seasonal and physicochemical variability, Jour. Environ. Chem. Ecotoxicol. 8 (2016) 1-8.

[5] R.A. Lawal, Y.N. Lohdip, J.N. Egila, Water quality assessment of Kampani River, Plateau state, Asian Rev. Environ. Earth Sci. 1 (2014) 30-34.
[6] A. Enuneku, L.I. Ezemonye, F. Adibeli, Heavy metal concentrations in surface water and bioaccumulation in fish (clarias gariepinus) of river owan, edo state Nigeria, Europ. Int. J. Sci. Technol. 2 (2013) 7-13.

[7] B.M. Desta, M.M. Weldemariam, Distribution of trace metals in two commercially important fish species (Tilapia zilli \& Oreochromis niloticus) sediment \& water from lake Czudbahri, Eastern Tigracy of Northern Ethiopia, Int. J. Sci. Res. Pub. 3 (2013) 2280-3153.

[8] B. Utete, T. Nhiwatiwa, M. Barson, N. Mabika, Metal correlation and mobility in sediments and water from the Gwebi River in the upper Manyame Catchement, Zimbabwe, Int. J. Water Sci. 2 (2013) 1-8.

[9] B.S. Bidyut, P.S. Hari, B. Lukumoni, Chemical speciation of copper and cadmium in Kameng river sediments using sequential extraction procedure, Int. Jour. Environ. Sci. 6 (2013)1-7.

[10] N. Mollazadeh, F. Moattar, A.R. Karbassi, N. Khorasani, Distribution of metals, chemical partitioning, pollution and origins in riverbed sediment, World Appl Sci. J. 21 (2013) 674-680.

[11] I.L. Dapam, E.G. Ibrahim, J.N. Egila, Assessment of physicochemical parameters and heavy metal speciation study of water and bottom sediments from river Jibam in Chip district of Pankshin local Government Area of Plateau state, Nigeria, Int. Organizat. Sci. Res. J. Appl. Chem. 9 (2016) 57-64

[12] M.A. Funtua, A.M. Dailimi, E.B. Agbaji, Speciation of heavy metals in the sediments of river Challawa- Kano, Nigeria, Jour. Multidis. Eng. Sci. Technol. 2 (2015) 19-27.

[13] O. Osakwe, P. Adowei, M. Horsefall, Evaluation of heavy metal species in bottom sediments from Imo River system, southeastern Nigeria, Res. Jour. Chem. Sci. 4 (2014) 23-30.

[14] G.O. Adewuyi, M.T. Osobamiro, Chemical speciation and potential mobility of some toxic metals in tropical agricultural soil, Res. Jour. Environ. Toxicol. 10 (2016) 159-165.

[15] A.O. Ogunfowakan, J.A.O. Oyekulu, G.O. Olutoni, A.O. Atoyebi, A. Lawal Speciation study of heavy metals in water and sediments from Asunle River of the Obafemi Awolowo University, Ile-Ife, Nigeria, Int. Jour. Environ. Protect. 3 (2013) 6-16.

[16] L.T-C. Juan, P.S-T. Nereid, F.Z. Pedro, R-D. Nely, M. Eduardo, G-S. Sergio, Speciation and sources of toxic metals in sediments of Lake Chapala, Mexico, Jour. Mexican Chem. Soc. 54 (2010) 79-87.

[17] A. Tessier, P.G. Campbell, M. Bisson, Sequential extraction procedure for the speciation of particulate trace metals, Anal. Chem. 51 (1979) 844-851.

[18] E.E. Ewa, A.I. Iwara, V.E. Offiong P.A. Essoka, G.N. Njar, Seasonal variation in heavy metal status of the Calabar River, cross river state Nigeria, Nigeria Jour. Nat. Sci. Res. 3 (2013) 11-18.

[19] K.M. Mohinddin, H.M. Zakir, K. Otomo, S. Sharmin, N. Shikazono, Geochemical distribution of trace metal pollutants in water and sediments of downstream of an urban river, Int. J. Environ. Sci. Tech . 7 (2010) 17-28.

[20] J.N. Egila, E.G. Ibrahim, M.A.G. Ibrahim, Speciation of selected trace metals in soil samples from Dumpsites in Lafia, Nasarawa State, Nigeria, Jour. Sci. Multidicip. Res. 5 (2013) 63-73. 